\title{
PENERAPAN STRATEGI INQUIRY MENGGUNAKAN READING INFUSION DAN SCIENCE REFLECTIVE JOURNAL WRITING UNTUK MENINGKATKAN KEMAMPUAN LITERASI SAINS SISWA SMP
}

\author{
Gina Gusliana1, Setiya Utari² dan Parsaoran Siahaan ${ }^{3}$ \\ 1. Teknologi Pangan, Fakultas Teknik, Universitas Pasundan, Jl. Dr. Setiabudhi No. 193, \\ Bandung, 40153, Indonesia \\ 2. Universitas Pendidikan Indonesia, Jl. Setiabudhi No. 229, Bandung, 40154, Indonesia \\ E-mail: ginagusliana@gmail.com
}

\begin{abstract}
ABSTRAK
Literasi sains merupakan kemampuan yang dipandang penting untuk dilakukan seperti kemampuan knowing, applying, dan reasoning, namun faktanya di lapangan kemampuan ini belum dilatihkan dengan baik,. Metode inkuiri memberikan sarana untuk melatihkan kemampuan-kemampuan tersebut, namun agar inkuiri terlaksana dengan baik dibutuhkan suatu strategi lain yaitu Strategi Reading Infusion (RI) dan Science Reflective Journal Writing (SRJ). Penelitian dengan metode quasy experiment desain Pretest and Postest Design with Matched Control Group melibatkan tiga kelas (103 siswa), bertujuan untuk memberikan gambaran cara yang dipandang lebih baik untuk melatihkan kemampuan literasi sains untuk konten optik dan alat optik. Hasil analisis data dengan menggunakan Kruskal Wallis serta hasil uji lanjutan Mann Whitney U Test dengan $\alpha=0,05$, menunjukkan bahwa kemampuan literasi sains yang meningkat secara signifikan adalah applying bagi kelas inkuiri menggunakan SRJ $(0,006<0,05 ;$ hasil uji lanjutan 0,002 <0,05), sedangkan untuk kemampuan lainnya (knowing dan reasoning) tidak terdapat perbedaan yang signifikan antara ketiga kelas.
\end{abstract}

Kata Kunci: inquiry, jenjang kemampuan, kognitif literasi sains, Reading Infusion (RI), Science Reflective Journal Writing (SRJ).

\begin{abstract}
Scientific literacy is an ability to be seen an important ability of knowing, applying, and reasoning, but the fact is this capability has not been properly trained. Inquiry method provides to train these abilities, but that inquiry performing well requires by adding another strategy, namely Reading Strategies Infusion (RI) and Science Reflective Journal Writing (SRJ). Research by the method quasy pretest and posttest experimental design with Matched Control Group Design involves three classes (103 students), aims to provide an overview on how to better perceived ability to train scientific literacy and cognitive ability for content optics and optical devices. Results of data analysis, sciencetific literacy ability which more improved significantly is applying ability for the strategy of inquiry using SRJ class (0,006 $<0,05$ and further test results $0.002<0.05$ ), whereas for the other abilities (knowing and reasoning) there is no significant difference between three classes.
\end{abstract}

Keywords: cognitive ability, inquiry, Reading Infusion (RI), Science Reflective Journal Writing (SRJ), scientific literacy TIMSS.

Received:27 November 2018 ; Accepted: 1 Februari 2019; Published: 4 Februari 2019 


\section{PENDAHULUAN}

Kualitas sumber daya suatu bangsa dapat dilihat dari kualitas pendidikan, yaitu dalam pembelajaran. Kualitas pembelajaran salah satunya berkaitan dengan kualitas membaca. Hal ini didukung oleh American Diploma Project tahun 2004, bahwa keterampilan membaca merupakan kunci sukses setelah pendidikan. Melalui membaca, informasi dan pengetahuan siswa akan lebih berkembang. Sehingga dapat kita katakan bahwa kualitas membaca berbanding lurus dengan kualitas SDM.

Berdasarkan data International Education Achievement (IEA) yang meneliti kualitas mambaca anak-anak di 31 negara menunjukkan bahwa kualitas baca anak-anak Indonesia berada pada urutan ke-29 dari 31 negara tersebut. Hal ini sangat mungkin terjadi karena indeks membaca Indonesia adalah 0,001, jadi dari seribu penduduk hanya satu yang memiliki minat baca tinggi. Berdasarkan fakta tersebut, tidak mengherankan jika Indonesia mempunyai indeks kualitas SDM (Human Development Index/ HDI) tahun 2013 hanya menempati peringkat ke-121 dari 185 negara.

Ilmu Pengetahuan Alam (IPA) berkaitan dengan sebuah proses mencari tahu tentang alam melalui proses penemuan, sehingga diharapkan dapat menjadi wahana bagi siswa untuk menerapkannya dalam kehidupan sehari-hari (Permen Diknas Nomor 22 Tahun 2006:377). Melalui pembelajaran IPA, salah satunya Fisika yang merupakan cabang ilmu IPA, sangat diharapkan dapat memberikan pengalaman nyata kepada siswa berupa kegiatan penyelidikan dalam rangka menjelajahi dan memahami alam sekitar.

Tetapi kenyataannya di lapangan, pembelajaran yang berlangsung masih bersifat informatif, tidak menghadirkan fenomena dalam kehidupan sehari-hari, kurang memberikan pengalaman nyata pada siswa, dan percobaan yang dilakukan bersifat verifikasi. Selain itu, peneliti juga melakukan studi pendahuluan menggunakan soal TIMSS (Trends in International Mathematics and Science Study) yang merupakan salah satu literasi sains di level kelas VIII (Martin, Michael 0 \&
Mullis, Ina V.S, 2011). Dari pengujian soal-soal fisika TIMSS tahun 1999 dan 2003 tersebut, ternyata siswa masih mempunyai kelemahan pada kemampuan-kemampuan TIMSS tahun 2011, yaitu kemampuan pengetahuan (knowing) 43,33\%, menerapkan (applying) 62\%, mengemukakan alas an (reasoning) 55,91\%. Jika dikaitkan dengan Taksonomi Anderson dan Krathwohl, siswa masih mempunyai kelemahan pada kemampuan kognitif. Kecenderungan pembelajaran seperti ini mungkin dialami oleh sekolah yang ada di Indonesia, sehingga prestasi Indonesia dalam aspek kemampuan kognitif di TIMSS pada bidang sains di level kelas VIII konten Fisika berada pada peringkat rendah.

Dari penjelasan tersebut, maka perlu proses pembelajaran fisika yang diharapkan dapat meningkatkan literasi sains siswa, karena proyek 2061 berfokus pada peningkatan literasi sains. Mengacu pada negara Singapura yang memiliki peringkat tertinggi TIMSS kelas VIII pada domain konten sains, metode pembelajaran yang digunakan adalah science inquiry (CPDD dalam Towndrow et.all, 2008). Pembelajaran secara inkuiri ilmiah (scientific inquiry) pun merupakan pembelajaran yang dianjurkan dalam kurikulum Indonesia, hal ini terlihat dalam latar belakang pembelajaran IPA di SMP. Sehingga, salah satu pembelajaran yang sangat cocok untuk meningkatkan kemampuan literasi sains siswa adalah inkuiri.

Mengacu pada National Science Education Standards (NRC) tahun 1996 (Towndrow et.all, 2008), pembelajaran menggunakan inkuiri meliputi tahap berikut:

- Mengidentifikasi dan bertanya (identifying and asking questions);

- Mendesain dan melakukan percobaan (designing and conducting experiments);

- Menganalisis data dan fakta (analyzing data and evidence);

- Menggunakan model dan penjelasan (using models and explanations);

- Mengkomunikasikan temuan (communicating findings).

Penelitian ini mengacu pada studi TIMSS (Trends in International Mathematics and Science Study) karena ditujukan untuk level kelas 4 dan 8. TIMSS 
bertujuan untuk mengungkapkan pencapaian matematika dan sains, gambaran pembelajaran pada konten matematika dan sains, juga meningkatkan belajar dan mengajar matematika dan sains. Kemampuan literasi sains pada domain kognitif TIMSS terdiri dari kemampuan knowing, applying, dan reasoning.

Tabel 1. Indikator Domain Kognitif TIMSS 2011

\begin{tabular}{|l|l|l|}
\hline \multicolumn{1}{|c|}{ Knowing } & \multicolumn{1}{|c|}{ Applying } & \multicolumn{1}{c|}{ Reasoning } \\
\hline $\begin{array}{l}\text { recall/ } \\
\text { recognize }\end{array}$ & $\begin{array}{l}\text { compare/ } \\
\text { contrast/ } \\
\text { classify }\end{array}$ & $\begin{array}{l}\text { analyze / solve } \\
\text { problems }\end{array}$ \\
\hline Define & use models & $\begin{array}{l}\text { integrate/ } \\
\text { synthesize }\end{array}$ \\
\hline Describe & Relate & $\begin{array}{l}\text { hypothesize/ } \\
\text { predict }\end{array}$ \\
\hline $\begin{array}{l}\text { ilustrate with } \\
\text { examples }\end{array}$ & $\begin{array}{l}\text { interpret } \\
\text { information }\end{array}$ & design/plan \\
\hline $\begin{array}{l}\text { use tools and } \\
\text { procedures }\end{array}$ & find solutions & draw conclusion \\
\hline & Explain & generalize \\
\hline & & evaluate \\
\hline & & justify \\
\hline
\end{tabular}

Terdapat aspek-aspek pada setiap kemampuan yang belum dapat difasilitasi oleh pembelajaran inkuiri, sehingga diperlukan beberapa strategi untuk dapat memfasilitasi kemampuan tersebut. Strategi yang dapat memfasilitasi kemampuankemampuan yang kurang dapat difasilitasi oleh pembelajaran inkuiri diantaranya strategi reading infusion (RI) dan science reflective journal writing (SRJ).

Reading infusion (RI) merupakan sebuah bacaan yang mempunyai keistimewaan yang berfokus pada dua komponen utama yaitu mengajar strategi pemahaman dan membangun domain pengetahuan melalui kata/ konsep yang terkait (Artley dalam Fang, 2010). Salah satu teknik yang dapat digunakan dalam membaca suatu artikel adalah teknik SQ3R (Survey, Question, Read, Recite, Review) yang dikemukakan oleh Francais P. Robinson (dalam handout Southern Illinois University Carbondale). Tahap survey dilakukan untuk mendapatkan gambaran umum membaca sebelum memulai membaca per kata. Tahap question dilakukan untuk memfokuskan perhatian pada informasi penting pada suatu bagian dengan memikirkan apa yang ditemukan melalui tahap survey. Tahap read dilakukan untuk mendapatkan jawaban yang telah disusun sebelumnya. Tahap recite dilakukan untuk menguji apakah pembaca telah mengerti materi. Tahap review dilakukan untuk meyakinkan bahwa pembaca telah memahami bacaan membantu siswa menguasai konsep

Science Reflective Journal Writing (SRJ) menurut Towndrow et all (2008) memberikan pengalaman kepada siswa untuk dapat mengidentifikasi dan merekam apa yang telah dipelajari. Dalam prakteknya, Towndrow (2008: 280) meminta siswa membuat SRJ dalam waktu lima menit dengan pertanyaan sebagai berikut:

- Question I have about today's lesson

- Something I have learned today

- Some thought-provoking incident in class today.

Beberapa kemampuan yang rendah adalah kemampuan ilustrate with examples dan kemampuan synthesize. Reading infusion adalah salah satu cara yang dapat dilakukan, yaitu dengan memberikan bahan bacaan berupa fenomena nyata yang terjadi dalam kehidupan sehari-hari yang berkaitan dengan konsep yang akan ia pelajari di awal pembelajaran, kemudian siswa diminta untuk menyintesis apa yang ia dapatkan dari bacaan tersebut. Sedangkan untuk meningkatkan kemampuan integrate/synthesize, generalize, evaluate, dan justify dapat dilakukan melalaui penggunaan strategi SRJ, yaitu dengan cara menuliskan beberapa hal mengenai apa yang siswa ingin tanyakan, apa yang telah dipelajari, dan apa yang menjadi penyebab kegagalan yang siswa alami dalam pembelajaran. Selain itu, inkuiri pun sangat ditunjang oleh kemampuan bertanya, NSTA \& AETS (Direktorat Tenaga Kependidikan, 2008: 25) menyatakan bahwa jantungnya inkuiri adalah kemampuan mengajukan pertanyaan dan mengidentifikasi penyelesaian masalah. Kemampuan ini juga dapat dibantu oleh strategi SRJ yang merupakan strategi yang dapat memfasilitasi kemampuan bertanya reflektif siswa, karena SRJ merupakan alat yang dapat mencatat aktivitas yang telah dilakukan dan memberikan kesempatan kepada siswa untuk mengungkapkan keraguan dan hambatan tentang sains. Dengan kata lain, SRJ merupakan alat komunikasi antara guru dengan siswa. 
Penelitian yang dilakukan merupakan pengembangan dari penelitian sebelumnya (Towndrow, 2008; Fang, 2010; Murbakara, 2011). Penelitian ini bertujuan untuk memberikan gambaran mengenai cara yang dipandang lebih baik untuk melatihkan kemampuan literasi sains untuk konten optik dan alat optik dengan cara membandingkan strategi inquiry menggunakan $R I$, strategi inquiry menggunakan SRJ, dan strategi inquiry menggunakan gabungan reading infusion dan science reflective journal writing terhadap literasi sains siswa.

\section{METODE PENELITIAN}

Metode penelitian yang digunakan adalah quasy experiment. Desain penelitian yang digunakan adalah pretest and postest design with matched control group. Penelitian ini terdiri dari satu kelas eksperimen dan dua kelas kontrol (kontrol 1 mendapat perlakuan inkuiri dengan RI, kontrol 2 mendapatkan perlakuan inkuiri dengan SRJ) dan satu kelas eksperimen yang mendapatkan perlakuan inkuiri dengan RI dan SRJ.

Tabel 2. Desain Penelitian

\begin{tabular}{|l|l|l|l|}
\hline Kelompok & Pre-test & Treatment & Post-test \\
\hline Eksperimen & $\mathrm{O}_{\mathrm{K}}, \mathrm{O}_{\mathrm{T}}$ & $\mathrm{X}_{1}$ & $\mathrm{O}_{\mathrm{K}}, \mathrm{O}_{\mathrm{T}}$ \\
\hline Kontrol I & $\mathrm{O}_{\mathrm{K}}, \mathrm{O}_{\mathrm{T}}$ & $\mathrm{X}_{2}$ & $\mathrm{O}_{\mathrm{K}}, \mathrm{O}_{\mathrm{T}}$ \\
\hline Kontrol II & $\mathrm{O}_{\mathrm{K}}, \mathrm{O}_{\mathrm{T}}$ & $\mathrm{X}_{3}$ & $\mathrm{O}_{\mathrm{K}}, \mathrm{O}_{\mathrm{T}}$ \\
\hline
\end{tabular}

Populasinya merupakan seluruh siswa kelas VIII pada salah satu SMP Negeri di kabupaten Bandung semester genap tahun pelajaran 2013/2014 yang terdiri dari sepuluh kelas. Sampel berjumlah 103 siswa (kelas eksperimen berjumlah 34 orang siswa, kelas kontrol 135 siswa, dan kelas kontrol 2 berjumlah 34 orang siswa) yang dipilih secara randomize matching cluster sampling (Ary et.all, 2010). Pemilihan subjek penelitian tidak merubah kelas, tetapi menggunakan kelas yang sebelumnya telah terbentuk. Tahap pertama adalah mencocokkan setiap kelas dengan variabel yang relevan dalam hal ini pretest. Dalam penelitian ini adalah kelas VIII di enam kelas yang memiliki guru IPA yang sama. Setelah didapatkan skor pretest dari keenam kelas tersebut kemudian diuji homogenitasnya menggunakan uji Barlett (Sudjana, 2005: 261).

Kemampuan literasi sains siswa diukur dengan menggunakan tes pilihan ganda sebanyak 29 soal yang telah valid, dmemiliki reliabitas tinggi tinggi $\left(r_{x y}=0,657\right)$ berdasarkan persamaan berikut.

$r_{x y}=\frac{n \sum x y-\left(\sum x\right)\left(\sum y\right)}{\sqrt{\left[\left(n \sum x^{2}\right)-\left(\sum x\right)^{2}\right]\left[\left(n \sum y^{2}\right)-\left(\sum y\right)^{2}\right]}}$

Soal tes literasi sains merupakan soal yang diadaptasi dari soal TIMSS standar. Sehingga soal yang dibuat diuji terlebih dahulu korelasinya dengan tes standar menggunakan uji koefisien korelasi Spearman Rank-Order (Minium, 1993: 157) sebagai berikut.

$$
r=\frac{n\left(\sum X Y\right)-\left(\sum X\right)\left(\sum Y\right)}{\sqrt{\left(n\left(\sum X^{2}\right)-\left(\sum X\right)^{2}\right)\left(n\left(\sum Y^{2}\right)-\left(\sum Y\right)^{2}\right)}}
$$

Berdasarkan hasil pengolahan, didapatkan bahwa nilai korelasi $(\mathrm{r})$ tabel adalah sebesar 0,421 , sehingga didapatkan bahwa soal padanan TIMSS memiliki korelasi sedang.

Penelitian dilakukan sebanyak lima kali pertemuan pada konten optik dan alat-alat optik. Sebelum perlakuan dilaksanakan, terlebih dahulu dilakukan pre-test, kemudian dilakukan post-test di setiap kelas.

Peningkatan penguasaan konsep siswa dilihat menggunakan selisih posttest dengan pretest pada setiap kemampuan TIMSS (knowing, applying, reasoning). Kemudian setiap peningkatan kemampuan diuji normalitasnya menggunakan Kolmogorov Smirnov.

Jika data terdistribusi normal, maka digunakan uji parametrik ANOVA satu jalur, tetapi jika data tidak terdistribusi normal maka dilakukan uji non parametrik Kruskall Wallis. Uji lanjutan (Post Hoc) dilakukan jika setelah melalui uji beda ratarata menghasilkan adanya perbedaan peningkatan menggunakan program aplikasi SPSS 1.6.

\section{HASIL DAN PEMBAHASAN a. Peningkatan Literasi Sains}




\section{1) Peningkatan Literasi Sains Kemampuan Knowing}

Skor posttest dan pretest literasi sains pada kemampuan knowing untuk setiap kelas dapat dilihat pada Gambar 1.

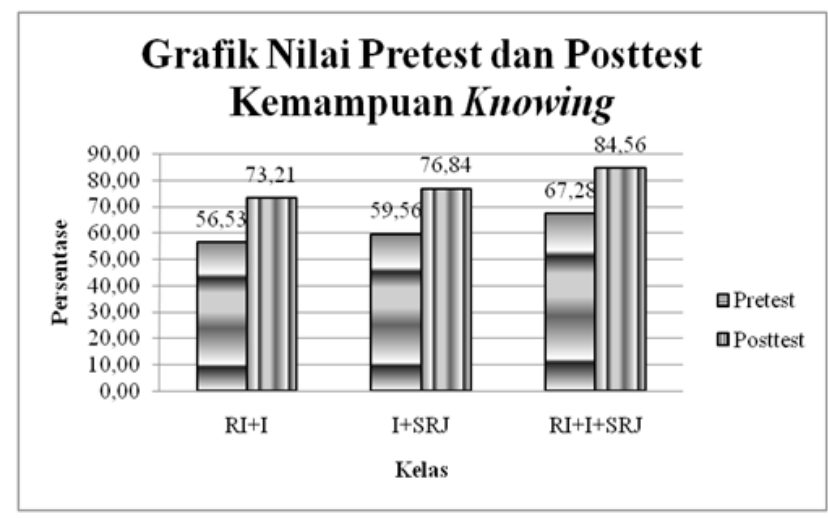

Gambar 1. Grafik Kemampuan Knowing

Setelah diuji normalitasnya, ketiga data tidak terdisribusi normal, sehingga beda rata-ratanya diuji menggunakan Kruskal Wallis. Berikut Tabel 3 merupakan hasil uji Kruskal Wallis.

Tabel 3. Hasil Uji Hipotesis Kemampuan Knowing

\begin{tabular}{|l|c|}
\hline & VAR00001 \\
\hline Chi-Square & .215 \\
Df & .2 \\
Asymp. Sig. & .898 \\
\hline
\end{tabular}

a. Kruskal Wallis Test

b. Grouping Variable: VAR00002
Berdasarkan Tabel 3, nilai signifikansi 0,898 > nilai signifikansi $\alpha=0,05$. Sehingga dapat disimpulkan bahwa tidak terdapat perbedaan peningkatan yang signifikan antara ketiga kelas.

Tidak adanya perbedaan peningkatan jenjang kemampuan kogntif antara kelas eksperimen, kontrol 1, dan kontrol 2, dikarenakan tidak adanya perbedaan setiap kelas dalam proses berinkuiri. Tabel 4 menyajikan persentasi dari rata-rata skor LKS dalam lima pertemuan. Persentase LKS yang dikerjakan oleh siswa di setiap kelas tidak jauh berbeda, hanya berbeda 1\%. Sehingga dapat disimpulkan bahwa RI tidak berdampak signifikan terhadap proses berinkuiri. Oleh karena itu kemampuan knowing yang erat kaitannya dengan RI tidak berbeda secara signifikan.

Tabel 4 Profil LKS Siswa

\begin{tabular}{cccccccc}
\multirow{2}{*}{ Kelas } & \multicolumn{9}{c}{ Pertemuan } & $\begin{array}{c}\text { Rata- } \\
\text { Rata }\end{array}$ & Persentase \\
\cline { 2 - 6 } & $\mathbf{1}$ & $\mathbf{2}$ & $\mathbf{3}$ & $\mathbf{4}$ & $\mathbf{5}$ & \\
\hline Eksperimen & 3.68 & 3.92 & 3.84 & 4.14 & 4.18 & 3.95 & 79.040 \\
\hline Kontrol 1 & 3.98 & 3.73 & 3.94 & 4.09 & 4.09 & 3.97 & 79.375 \\
\hline Kontrol 2 & 3.71 & 3.48 & 4.13 & 4.14 & 4.05 & 3.90 & 78.070
\end{tabular}




\section{2) Peningkatan Literasi Sains Kemampuan Applying}

Berikut ini grafik yang menunjukkan skor pretest dan posttes setiap kelas pada kemampuan applying.

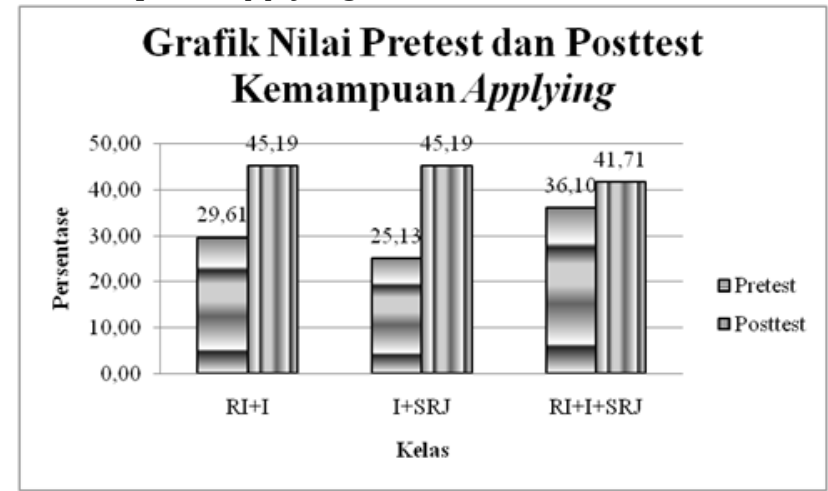

Gambar 2. Grafik Kemampuan Applying

Hasil uji normalitas, menunjukkan bahwa terdapat kelas yang tidak terdistribusi normal, sehingga beda rata-ratanya diuji menggunakan Kruskal Wallis. Berikut Tabel 5 merupakan hasil uji Kruskal Wallis.

Tabel 5. Hasil Uji Beda Kruskal Wallis pada \begin{tabular}{|l|r|}
\hline \multicolumn{2}{|c|}{ Kemampuan Applying } \\
\hline & VAR00001 \\
\hline Chi-Square & 10.368 \\
Df & 2 \\
Asymp. Sig. & .006 \\
\hline
\end{tabular}
a. Kruskal Wallis Test
b. Grouping Variable: VAR00002

Tabel 5 menunjukkan bahwa nilai signifikansi kemampuan applying lebih kecil $(0,006)$ daripada $\alpha=0,05$ sehingga dapat disimpulkan bahwa terdapat perbedaan yang signifikan antara ketiga kelas. Untuk mengetahui kelas mana yang berbeda, maka dilakukan uji lanjutan non parametrik Mann Whitney $U$ test dua ekor dengan $\alpha=0,05$.
Tabel 6. Hasil Uji Mann Whitney U Test

\begin{tabular}{|c|c|c|}
\hline \multicolumn{2}{|c|}{ Kelas } & $\begin{array}{c}\text { Nilai signifikansi } \\
\text { (Asymp. Sig) } \\
\text { dengan } \boldsymbol{\alpha}=\mathbf{0 , 0 5}\end{array}$ \\
\hline $\begin{array}{c}\text { RI + } \\
\text { Inkuiri }\end{array}$ & $\begin{array}{c}\text { RI + Inkuiri } \\
+ \text { SRJ }\end{array}$ & 0,035 \\
\hline & $\begin{array}{c}\text { Inkuiri + } \\
\text { SRJ }\end{array}$ & 0,278 \\
\hline $\begin{array}{c}\text { Inkuiri + } \\
\text { SRJ }\end{array}$ & $\begin{array}{c}\text { RI + Inkuiri } \\
+ \text { SRJ }\end{array}$ & 0,002 \\
\hline
\end{tabular}

Karena pengujian Mann Whitney menggunakan dua ekor, maka daerah penolakan Ho adalah $\alpha=0,025$. Jadi, hanya kelas inkuiri menggunkana SRJ (kontrol 2) yang memiliki perbedaan signifikan dengan kelas inkuiri menggunakan RI dan SRJ (eksperimen).

Kemampuan applying erat kaitannya dengan strategi SRJ yang diberikan. Pertanyaan pertama dalam SRJ dapat melatih kemampuan membandingkan, menggunakan model, dan menghubungkan dalam mengajukan pertanyaan baik itu bersifat tertutup, klarifikasi, maupun pendalaman. Pertanyaan kedua dapat melatih

kemampuanmengklasifikasi,menginterpretasik an informasi, dan menjelaskan. Pertanyaan terakhir dalam SRJ dapat melatih kemampuan menemukan solusi, karena saat siswa mengemukakan penyebab kegagalannya siswa akan menemukan solusi untuk pembelajaran selanjutnya agar tidak mengulangi kegagalannya lagi. Selain itu, ada proses dimana siswa mendapat pengetahuan lebih, yaitu saat pembahasan SRJ di pertemuan selanjutnya, sehingga pengetahuan siswa akan lebih kuat mengenai konsep yang telah dipelajari.

Kelas eksperimen juga mendapatkan SRJ dalam penelitian ini, tetapi memiliki peningkatan yang lebih rendah daripada kelas kontrol 1. Mengacu pada profil SRJ pada Tabel 5 untuk kedua kelas, kelas eksperimen memiliki persentase yang lebih kecil. Alasan lain mengapa kelas eksperimen memiliki peningkatan yang lebih 
kecil adalah berdasarkan hasil wawancara dengan beberapa siswa, mereka mengutarakan bahwa tugas yang harus dikerjakan terlalu banyak, yaitu RI juga SRJ, selain itu mereka belum terbiasa dengan praktikum. Sehingga ada tiga hal baru yang harus siswa kerjakan yaitu RI, berinkuiri, dan SRJ.

\section{3) Peningkatan Literasi Sains Kemampuan Reasoning}

Grafik yang menunjukkan skor pretest dan posttest setiap kelas pada kemampuan reasoning ditunjukkan oleh Gambar 3 berikut.

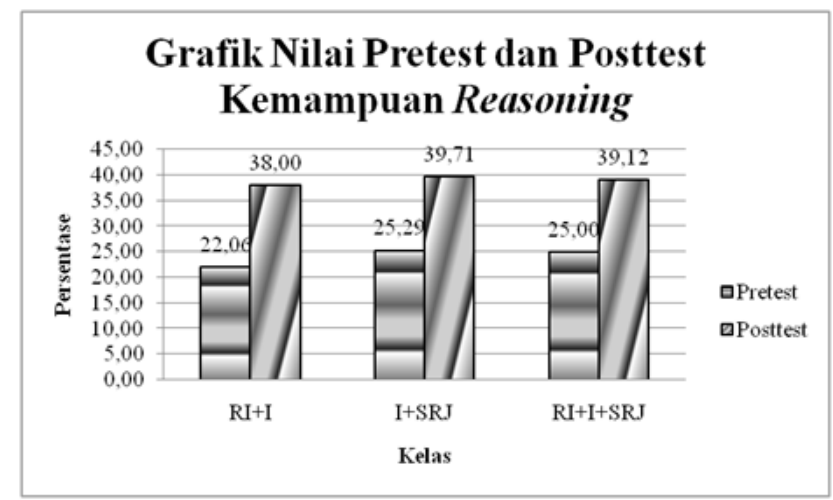

Gambar 3. Grafik Kemampuan Reasoning

Berdasarkan hasil uji normalitas menunjukkan bahwa ada kelas yang tidak terdistribusi normal, sehingga dilakukan uji non parametrik Kruskal Wallis yang hasilnya dapat dilihat pada Tabel 6 berikut.

Tabel 6 Hasil Uji Beda Kruskal Wallis pada Kemampuan Reasoning

Test Statistics ${ }^{\mathbf{a}, \mathbf{b}}$
\begin{tabular}{|l|r|}
\hline & VAR00001 \\
\hline Chi-Square & .024 \\
Df & 2 \\
Asymp. Sig. & .988 \\
\hline
\end{tabular}
a. Kruskal Wallis Test
b. Grouping Variable:
VAR00002

Berdasarkan Tabel 6 nilai sginifikansi lebih besar dari $\alpha=0,05$, ini menunjukkan bahwa tidak terdapat perbedaan yang signifikan atara ketiga kelas.

Tidak adanya perbedaan dalam kemampuan reasoning dapat terjadi karena kemampuankemampuan reasoning seperti menganalisis, menyintesis, behipotesis, dan mendesain samasama telah dilatihkan pada proses berinkuiri. Sedangkan kemampuan reasoning lainnya seperti menyimpulkan, mengeneralisasi, mengevaluasi, dan menyungguhkan dilatihkan pada proses konfirmasi, presentasi, dan menyimpulkan yang pada prakteknya tidak terlaksana dengan baik.

\section{b. Profil Reading Infusion (RI) Siswa}

Reading Infusion (RI) dilakukan sebagai dasar untuk berinkuiri dengan tahapan Reading, Survey, Question, Read, Recite, dan Review (RSQ3R). Kemampuan Read tidak dapat diukur karena dilakukan di rumah. Berikut menunjukkan profil RI di kelas eksperimen.

Tabel 7.Profil Reading Infusion (RI) Kelas Eksperimen

\begin{tabular}{|c|r|r|r|r|}
\hline \multirow{2}{*}{$\begin{array}{c}\text { Pertemuan } \\
\text { ke- }\end{array}$} & \multicolumn{4}{|c|}{ Skor rata-rata } \\
\cline { 2 - 5 } & Survey & \multicolumn{1}{c|}{ Question } & Recite & Review \\
\hline 1 & 1,61 & 3,13 & 2,74 & 3,68 \\
\hline 2 & 1,62 & 3,72 & 3,46 & 10,72 \\
\hline 3 & 2,03 & 3,52 & 3,12 & 6,09 \\
\hline 4 & 1,16 & 3,66 & 3,24 & 10,00 \\
\hline 5 & 1,28 & 3,38 & 3,22 & 10,00 \\
\hline Rata-rata & 1,54 & 3,48 & 3,16 & 8,10 \\
\hline
\end{tabular}

Berdasarkan tabel di atas, kemampuan Survey sebesar 1,54 artinya siswa hanya dapat menyebutkan ide utama bacaan sampai $25 \%$ saja. Kemampuan Question sebesar 3,84\% artinya ratarata siswa mengajukan 1 pertanyaan berhubungan dengan konsep yang dibaca dan menggunakan format pertanyaan $5 \mathrm{~W} 1 \mathrm{H}$. Sedangkan kemampuan Review sebesar 8,10 dari 12,6 skor review terbesar artinya hanya $64,27 \%$ siswa yang dapat melengkapi diagram konsep atau sebesar 64,27\% siswa dapat menyimpulkan hasil bacaan.

Kelas kontrol 2 mendapatkan perlakukan inkuiri ditambah dengan RI di awal 
pembelajaran, sama halnya dengan RI yang diberikan di kelas eksperimen. Hasil profil RI setiap pertemuan di kelas kontrol ditunjukkan pada tabel berikut.

Tabel 8. Profil Reading Infusion (RI) Kelas Kontrol 1

\begin{tabular}{|c|c|c|c|c|}
\hline \multirow{2}{*}{$\begin{array}{l}\text { Pertemuan } \\
\text { ke- }\end{array}$} & \multicolumn{4}{|c|}{ Skor Rata-rata } \\
\cline { 2 - 5 } & Survey & Question & Recite & Review \\
\hline 1 & 2,12 & 3,23 & 2,77 & 1,90 \\
\hline 2 & 2,92 & 3,31 & 3,14 & 10,86 \\
\hline 3 & 1,84 & 2,92 & 2,45 & 8,89 \\
\hline 4 & 1,56 & 3,54 & 2,83 & 9,59 \\
\hline 5 & 1,73 & 3,25 & 3,20 & 9,80 \\
\hline Rata-rata & 2,03 & 3,25 & 2,88 & 8,21 \\
\hline
\end{tabular}

Berdasarkan Tabel 8 kemampuan survey siswa yang mendapatkan perlakuan inkuiri ditambahkan dengan RI sebesar 2,03 yang berarti siswa telah dapat mengungkapkan ideide pokok bacaan dari $25 \%$ sampai dengan 49\%. Kemudian kemampuan question siswa sebesar 3,25 yang berarti rata-rata siswa telah dapat mengajukan sebuah pertanyaan berhubungan dengan konsep yang dibaca dan menggunakan format pertanyaan $5 \mathrm{~W} 1 \mathrm{H}$. Kemampuan recite siswa sebesar 2,88 yang berarti siswa umumnya dapat menjawab salah satu pertanyaan dengan benar. sedangkan kemampuan review sebesar 8,21 dari rentang nilai 0 sampai dengan 12,6 , hal ini berarti $65,14 \%$ siswa dapat menyimpulkan hasil bacaaan.

\section{c. Profil Science Reflective Journal Writing (SRJ) Siswa}

Science Reflective Journal Writing (SRJ) diberikan kepada kelas eksperimen dan kelas kontrol 2 pada akhir setiap pembelajaran. SRJ meliputi tiga pertanyaan yaitu:

a. Pertanyaan apa yang ingin kamu tanyakan?

b. Pengetahuan apa yang kamu dapatkan?

c. Apa yang menjadi penyebab kegagalan dalam pembelajaran?

Maka, profil SRJ yang didapat meliputi ketiga pertanyaan tersebut. SRJ setiap pertemuan yang didapat kemudian diberi skor dan dibuat rataratanya. Tabel 9 meunjukkan profil SRJ untuk kelas eskperimen.
Tabel 9. Profil Science Reflectve Journal Writing (SRJ) Kelas Eksperimen

\begin{tabular}{|c|c|c|c|}
\hline \multirow{2}{*}{$\begin{array}{c}\text { Perte- } \\
\text { muan } \\
\text { ke- }\end{array}$} & $\begin{array}{c}\text { Mengaju- } \\
\text { kan } \\
\text { Pertanyaan }\end{array}$ & $\begin{array}{c}\text { Mengemuka } \\
\text { kan } \\
\text { Pengetahuan } \\
\text { yang } \\
\text { Didapatkan }\end{array}$ & $\begin{array}{c}\text { Mengemuka- } \\
\text { kan } \\
\text { Penyebab } \\
\text { Kegagalan }\end{array}$ \\
\hline 1 & 2,75 & 2,60 & 2,10 \\
\hline 2 & 2,85 & 2,24 & 2,06 \\
\hline 3 & 2,79 & 2,62 & 1,60 \\
\hline 4 & 3,28 & 2,40 & 1,90 \\
\hline 5 & 2,83 & 2,52 & 1,62 \\
\hline $\begin{array}{c}\text { Rata- } \\
\text { rata }\end{array}$ & 2,90 & 2,48 & 1,85 \\
\hline
\end{tabular}

Tabel 9 menunjukkan bahwa kemampuan siswa dalam mengajukan pertanyaan berada pada skor rata-rata 2,90 maka dapat disimpulkan bahwa siswa cencerung mengajukan pertanyaan berkaitan dengan materi yang dipelajari, bersifat terbuka tetapi bersifat klarifikasi. Kemudian kemampuan siswa dalam mengemukakan pengetahuan yang didapatkan memiliki skor rata-rata 2,48 artinya siswa umumnya hanya menuliskan poin-poin penting yang telah dipelajari tanpa aadanya penjelasan. Kemudian, kemampuan siswa dalam mengemukakan penyebab kegagalan berada pada skor rata-rata 1,85 artinya siswa umumnya menuliskan penyebab kegagalan tetapi tidak berhubungan dengan pembelajaran.

Selain kelas eksperimen, kelas yang mendapatkan SRJ adalah kelas kontrol 2. Sama halnya dengan kelas eksperimen, kelas kontrol 2 juga mendapatkan SRJ di akhir setiap pembelajaran. Berikut Tabel 10 yang menunjukkan profil SRJ kelas kontrol 2.

Tabel 10. Profil Science Reflective Journal Writing (SRJ) Kelas Kontrol 2

Perte- Skor Rata-Rata 


\begin{tabular}{|c|c|c|c|}
\hline $\begin{array}{l}\text { muan } \\
\text { ke- }\end{array}$ & $\begin{array}{l}\text { Mengaju- } \\
\text { kan } \\
\text { Pertanyaan }\end{array}$ & $\begin{array}{l}\text { Mengemuka- } \\
\text { kan } \\
\text { Pengetahuan } \\
\text { yang } \\
\text { Didapatkan }\end{array}$ & $\begin{array}{l}\text { Mengemuka- } \\
\text { kan } \\
\text { Penyebab } \\
\text { Kegagalan }\end{array}$ \\
\hline 1 & 3,15 & 2,7 & 2,93 \\
\hline 2 & 2,49 & 2,6 & 2,14 \\
\hline 3 & 2,98 & 2,5 & 1,85 \\
\hline 4 & 3,62 & 2,5 & 2,13 \\
\hline 5 & 3,29 & 2,5 & 2,19 \\
\hline $\begin{array}{c}\text { Rata- } \\
\text { rata }\end{array}$ & 3,10 & 2,55 & 2,25 \\
\hline
\end{tabular}

Berdasarkan Tabel 4.11 kemampuan siswa di kelas kontrol 2 dalam mrngajukan pertanyaan memiliki skor rata-rata 3,10 yang artinya siswa umumnya mengajukan pertanyaan berkaitan dengan materi yang dipelajari, bersifat terbuka tetapi bersifat klarifikasi. Kemampuan siswa dalam mengemukakan pengetahuan yang didapatkan memiliki skor rata-rata 2,55 artinya siswa telah mampu Menuliskan satu pengetahuan yang dipelajari disertai penjelasan. Sedangkan kemampuan siswa dalam mengemukakan penyebab kegagalan memiliki skor rata-rata 2,25 artinya siswa umumnya dapat menuliskan penyebab kegagalan tetapi tidak berhubungan dengan pembelajaran.

Hasil analisis data tidak sesuai dengan asumsi sebelumnya bahwa dengan adanya dua perlakuan, maka kemampuan literasi sains akan meningkat. Hal ini terjadi karena berdasarkan hasil wawancara, siswa mengutarakan bahwa siswa keberatan dan bosan dalam mengerjakan tugas yang terlalu banyak dengan jangka waktu yang terhitung cepat yaitu 2 hari sehingga siswa kurang dapat fokus. Jika ditelusuri dari sisi psikologinya, Maltin (2009) berpendapat bahwa ada salah satu jenis perhatian (attention) yaitu perhatian yang terbagi (divided attention) yaitu merupakan salah satu bentuk pemusatan aktivitas mental pada dua atau lebih kegiatan yang dilakukan pada waktu yang bersamaan. Pada banyak kasus, keakuratan dari hasil kegiatan akan menurun terutama jika kegiatan itu menantang atau membutuhkan perhatian yang lebih. Menurutnya, untuk orang yang belum terbiasa membagi perhatiannya, maka akan menimbulkan efek yang kurang baik namun jika sudah terbiasa atau terlatih tidak akan menimbulkan efek yang buruk. Sehingga siswa yang berada pada kelas eksperimen tidak mengalami peningkatan kemampuan literasi sains yang signifikan. Sedangkan untuk kelas kontrol mengalami pengingkatan sesuai dengan penelitian sebelumnya yang meunjukkan bahwa kemampuan literasi meningkat melalui metode inkuiri ditambah RI maupun SRJ.

\section{KESIMPULAN}

Peningkatan literasi sains tidak berbeda secara signifikan untuk strategi pembelajaran inkuiri menggunakan RI dibandingkan dengan strategi pembelajaran inkuiri menggunakan RI dan SRJ. Sedangkan bagi pembelajaran strategi inkuiri menggunakan SRJ lebih meningkatkan literasi sains pada kemampuan applying dibandingkan dengan pembelajaran strategi inkuiri menggunakan RI dan SRJ.

Penulis menyarankan beberapa hal bagi pengelola pendidikan yang akan menggunakan Reading Infusion (RI) sebaiknya digunakan untuk konten yang memiliki pengetahuan dasar lebih banyak seperti konten optik. Penelitian ini dipengaruhi oleh waktu mengajar, jika alokasi waktunya memungkinkan, RI sebaiknya dilaksanakan di dalam pembelajaran, tetapi jika tidak memungkinkan sebaiknya ditambahkan lembar keterangan kejujuran siswa dalam mengisi RI. Sehingga kegiatan inkuiri yang merupakan kegiatan pengembangan setelah RI akan terlaksana dengan baik dan waktu yang dibutuhkan untuk berinkuiri tidak lama.

Penelitian ini dilakukan pada jenjang SMP yang sebaiknya menggunakan salah satu strategi tambahan saja dalam pembelajaran, seperti yang dilakukan terhadap kelas kontrol 1 yaitu strategi inkuiri ditambah RI dan kelas kontrol 2 yaitu strategi inkuiri ditambah SRJ saja. perlu adanya penelitian lebih lanjut menggunakan strategi RI dan SRJ dalam inkuiri pada konten lain di SMP atau jenjang SMA, sehingga akan diketahui apakah konten dan jenjang pendidikan berpengaruh terhadap literasi sains siswa. 


\section{DAFTAR PUSTAKA}

Ary, D. dkk. (2010). Introduction to Research in Education. USA: Wadswoth, Cengage Learning.

Depdiknas. (2013). Standar Isi untuk Satuan Pendidikan Dasar dan Menengah. Jakarta: Depdiknas.

Fang, Z \& Wei, Y. (2010). Improving Middle School Students' Science Literacy Through Reading Infusion. The Journal of Educational Research, 103:262-273, 2010.

Ministry of Education. (2007). Science Syllabus Lower Secondary Normal (Tehnical). Singapura: Curriculum Planning \& Development Design.

Minium, E. dkk. (1993). Statistical Reasoning in Psychology and Education. USA: John Wiley \& Sons, inc.

Project 2061: Science fo All Americans. (1989). America: A Publication of the American Physicological Society Vol. 32 No. 5.

Robinson, Francais P. Handout Southhern Illinois University Carbondale.

Selçuk, G.S. dkk. (2008). The Effects of Inquiry Instruction on Physics Achievement, Inquiry Performance and Strategy Use. Latin American Journal Physics Education volume 2 No. 3 September 2008.

Southern Illinois University Carbondale. SIUC Writing Center (http://write.siu.eduHandoutsThe $\% 20$ SQ3R\%20Method\%20of\%20Study.pdf) diakses 16 September 2013.

Sudjana. (2005). Metoda Statistika Edisi 6. Bandung: Tarsito.

TIMSS 2011 Science Framework. (2011). (http://timssandpirls.bc.edu/timss201 1/downloads/TIMSS2011_Frameworks -Chapter2.pdf) diakses 15 September 2013.

TIMSS-PIRLS_Australian-Highlights. (2011). (http://www.acer.edu.audocumentsTI MSS-PIRLS_Australian-Highlights.pdf) diakses 15 Spetember 2013.

Toharudin, Uus., Hendrawati, Sri., Rustaman, Andrian. (2011). Membangun Literasi
Sains Peserta Didik. Bandung: Humaniora.

Towndrow., Philip, A., dan Ling, Tan Aik. (2008). Promoting Inquiry Through Science Reflective Journal Writing. Eurasian Journal of Mathematics, Science \& Technology Education 4(3), 279-283. 